\title{
DESKRIPSI GEJALA STRES AKADEMIK DAN KECENDERUNGAN PILIHAN STRATEGI KOPING SISWA BERBAKAT
}

\author{
Amy Noerul Azmy ${ }^{1(a)}$, Achmad Juntika Nurihsan ${ }^{1}$, dan Eka Sakti Yudha ${ }^{1}$
}

\begin{abstract}
The description of academic stress and tendencies of using coping strategies in the gifted students. This study aims to describe the general conception of an academic stress of gifted students, tendencies of coping strategies they use, and to plan an appropriate guidance and counseling program to manage an academic stress of gifted students. This study used a descriptive method with nonprobability sampling technique and specifically took the sample by using purposive sampling. The sample is collected from gifted students of tenth-graders at SMA Negeri 4 Bandung year 2015/2016. The result showed that academic stress of gifted students is in the medium category with a percentage of 76.92. On the other hand, the tendencies of the gifted students on using coping strategies showed that the students tend to use Emotion Focused Coping, with a percentage of $53.84 \%$. This shows that gifted students need a special attention on how to cope with problems so that it does not result in a negative way. Therefore, an appropriate service that is suitable for the needs of gifted students is required. The recommendation from this study is addressed to the school's guidance and counseling committee, teachers, and other researchers.
\end{abstract}

Keywords: Academic Stress, Coping, Gifted Students, Guidance and Counseling Program.

INDONESIAN JOURNAL OF EDUCATIONAL COUNSELING

Website: http://ojs.ejournal.id/index.php/ijec

Permalink: http://ojs.ejournal.id/index.php/ijec/article/view/120

How to cite (APA): Azmy, A. N., Nurihsan, A. J., \& Yudha, E. S. (2017). Deskripsi gejala stress akademik dan kecenderungan pilihan strategi koping siswa berbakat. Indonesian Journal of Educational Counseling, 1(2), 197 208.

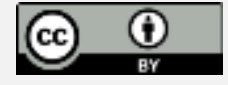

This is an open access article distributed under the terms of the Creative Commons Attribution 4.0 International License, which permits unrestricted use, distribution, and reproduction in any medium, provided the original work is properly cited.

\section{PENDAHULUAN}

Masa remaja merupakan masa perubahan. Perubahan tersebut terjadi baik dari proses berpikir, gejolak emosional, perubahan sosial, dan minat terhadap suatu hal yang baru. Perubahan-perubahan tersebut perlu diperhatikan dengan baik. Karena pada masa ini, remaja sedang mengalami masa kritis. Masa dimana terjadinya perubahan tekanan baik secara sosial, dan akademis mengharuskan remaja memiliki banyak peran dan tanggung jawab yang berbeda dari masa sebelumnya. Di masa remaja, prestasi dan minat sosial

\footnotetext{
${ }^{1}$ Departemen Psikologi Pendidikan dan Bimbingan, FIP Universitas Pendidikan Indonesia.

a Email: amynoerul@gmail.com.
} 
menjadi hal yang penting. Remaja mulai merasakan bahwa kehidupannya saat ini akan menentukan di masa depan. Contohnya kegagalan dan keberhasilan yang dicapai sekarang akan berpengaruh terhadap keberhasilan di masa yang akan datang. Suatu harapan yang ditetapkan oleh remaja ini terkadang tidak sesuai dengan tuntutan lingkungan dimana remaja berada, termasuk remaja berbakat, hal tersebut akan menimbulkan tekanan. Ellen Winner (Santrock, 2007: 11) mendeskripsikan bahwa remaja berbakat memiliki karakteristik sebagai berikut; 1) kematangan (precocity) remaja berbakat lebih cepat matang dibandingkan teman pada seusianya; 2) berkembang menurut tempo dan caranya sendiri, seperti pada proses belajar remaja berbakat memiliki cara sendiri dalam memecahkan masalah secara unik; 3) dorongan untuk menguasai lebih tinggi, dikarenakan mereka memiliki obsesi dan memperlihatkan minat yang tinggi; 4) keterampilan pemrosesan-informasi, remaja berbakat belajar dengan kecepatan tinggi, lebih cepat memproses informasi dengan menggunakan strategi yang lebih baik.

Siswa kelas X merupakan remaja awal yang dihadapkan pada beberapa halhal yang baru mereka temui seperti teman dari berbagai latar belakang, lingkungan dan tuntutan akademik yang berbeda dari sebelumnya. Siswa berbakat merupakan salah satu bagian dari keseluruhan remaja yang dihadapkan pada situasi yang baru. Hal ini akan menjadi tantangan bagi siswa berbakat, jika terjadi suatu tekanan yang dirasakan siswa berbakat dikelola dengan baik maka hasilnya akan baik. Sebaliknya, jika tekanan tersebut tidak dikelola dengan baik oleh siswa berbakat akan berdampak negatif. Tekanantekanan tersebut oleh Lazarus dan Folkman (1984) biasa disebut dengan stres yaitu akibat dari perasaan kecewa karena adanya ketidaksesuaian harapan dan kenyataan.

Yusuf (2011: 101) mengemukakan bahwa stress merupakan fenomena psikofisik yang bersifat manusiawi, dalam arti bahwa stress itu bersifat inheren dalam diri setiap orang dalam menjalani kehidupannya sehari-hari. Lazarus dan Folkman (1984) Stres terjadi apabila adanya ketidakseimbangan antara tuntutan dan kemampuan Artinya, stres yang dialami oleh siswa berbakat erat kaitannya dengan sumber stres. Jika siswa berbakat memiliki kemampuan untuk memenuhi tuntutan lingkungan maka stres akan dikelola secara positif. Sebaliknya jika siswa berbakat merasa bahwa dirinya lemah dan tidak mampu untuk memenuhi tuntutan lingkungan maka stres akan berdampak negatif.

Beck \& Judith (1998) juga menjelaskan bahwa, stres akan berdampak negatif jika individu menilai dirinya tidak mampu dalam mengatasi hambatan atau tekanan yang datang sehingga akan berpengaruh terhadap cara berpikir serta berperilaku. 
Stres yang dialami oleh siswa berbakat pada penelitian ini erat kaitannya dengan akademik. Carveth (Misra \& McKean, 2000) menjelaskan bahwa stres akademik atau academic stressor bersumber dari proses belajar mengajar yang mempengaruhi proses berpikir, fisik, emosi dan perilaku yang timbulkan. Kondisi ini terjadi karena adanya beberapa hal yang timbul khususnya pada siswa berbakat harga diri yang rendah, perfeksionis, kepekaan yang berlebihan (supersensitivity), kurangnya keterampilan sosial, dukungan sosial yang rendah, isolasi sosial, harapan yang tidak realistis dan tidak tersedianya pelayanan pendidikan yang sesuai (Munandar, 2002).

Ketika individu mengalami stres akan muncul reaksi dari stressor yang dialami nya Yusuf (2011: 112) membagi kedalam empat reaksi yaitu, (1) reaksi fisik yang ditandai dengan munculnya kelehan fisik seperti kesulitan tidur, merasa sakit kepala, telapak tangan sering berkeringat; (2) reaksi emosional ditandai dengan munculnya reaksi dari perasaan yang merasa diabaikan, tidak memiliki kepuasan, cemas; (2) reaksi perilaku atau behavioral ditandai bersikap agresif, membolos, dan berbohong untuk menutupi kesalahan;(4) reaksi proses berpikir, ditandai dengan kesulitan konsentrasi, perfeksionis, berpikir negatif hingga tidak memiliki priotitas hidup. Keempat reaksi ini yang akan mengungkap gejala stres akademik siswa berbakat ketika berkenaan dengan stressor yang dialaminya.

Ketika individu memiliki permasalahan atau mengalami suatu hal keadaan tertekan. Individu akan menceritakan permasalahan orang yang dipercaya, menangani masalahnya sendiri, rekreasi, mencari perhatian orang lain dan macam lainnya. Secara alamiah seseorang ketika dihadapkan pada situasi yang menimbulkan tekanan akan mencoba untuk mangatasinya baik secara positif maupun negatif (Cooper \& Davidson, 1991; Feldman, 1997; Lazarus; 1976). Cara untuk mengatasinya dapat disebut dengan koping (coping) (Santrock, 2007: 299). Lazarus dan Folkman (1984: 141) mendefinisikan Koping mengacu pada sesuatu yang dilakukan individu untuk mengatasi tuntutan yang membebani karena diluar kemampuan diri individu. Waiten dan Lloyd (Yusuf, 2011) mengemukakan koping merupakan upaya-upaya untuk mengatasi, mengurangi atau mentoleransi ancaman yang membebani perasaan karena stress.

Berbeda dengan Davidson (Aldwin, 2007), bahwa esensi koping berupa penghindaran yaitu suatu usaha menghindar untuk mengakui bahwa memang ada masalah yang harus diatasi atau menolak melakukan sesuatu untuk mengatasi masalah tersebut dengan penghindaran (avoidance coping) berfokus pada masalah dan emosi. 
Aldwin \& Yancura (2004) memaparkan strategi koping sebagai suatu perubahan kognitif dan perilaku yang berlangsung terus menerus untuk mengatasi tuntutan eksternal atau internal yang dinilai sebagai beban yang melampaui sumber daya individu tersebut.

Lazarus \& Folkman (1984: 148-150) mengkategorikan menjadi dua strategi koping, (1) Problem focused coping, yaitu usaha individu dalam mengatasi stress dengan cara mengatur dan mengubah masalah atau lingkungan yang menyebabkan terjadinya tekanan. Tujuan dari problem focused coping untuk mengurangi tuntutan dari lingkungan menekan atau memperluas sumber daya untuk mengatasinya; (2) Emotion focused coping, yaitu usaha indivu dalam mengatasi stress dengan mengatur respon emosional dalam rangka menyesuaikan diri dengan dampak yang akan ditimbulkan oleh suatu kondisi atau situasi yang penuh tekanan. Koping bukan sebuah proses yang berdiri sendiri melainkan perlu adanya pengaruh dari berbagai tuntutan dan sumber daya yang terdapat di lingkungan. Lazarus \& Folkman (1984: 159) membedakan sumber coping berdasarkan kaitannya dengan individu mapun lingkungan. Sumber-sumber yang berasal dari diri individu meliputi kesehatan dan tenaga, keyakinan yang positif, kemampuan memecahkan masalah. Sumber yang berasal dari lingkungan meliputi dukungan sosial dan sumber daya material. Dalam setting pendidikan dukungan sosial diperoleh dengan adanya lingkungan sekolah yang kondusif dan efektif sehingga dapat membantu siswa untuk memenuhi keinginan yang sesuai kemampuan. Tentunya kemampuan-kemampuan yang perlu dimiliki individu perlu dikembangkan secara optimal Salah satunya dengan adanya bimbingan. Bimbingan bagi anak berbakat dapat membantu mengembangkan toleransi, mendorong siswa menuju aktualisasi diri. Telah dikemukakan sebelumnya bahwa anak berbakat rentan akan stres disebabkan ketidakmampuannya untuk mengatasi ketegangannya. Dengan adanya program bimbingan dan mengetahui strategi koping yang tepat bagi remaja berbakat dapat membimbing mereka untuk mengembangkan keterampilan antarpribadi serta pemecahan masalah dengan kemampuan intelektual yang dimiliki (Munandar, 2014: 394).

Sejalan dengan hasil wawancara yang dilakukan oleh peneliti dengan guru BK di SMA Negeri 4 Bandung memaparkan bahwa SMAN 4 Bandung tidak memiliki kelas khusus untuk siswa bakat, hanya saja SMAN 4 Bandung merupakan sekolah berbasis inklusi, sehingga terdapat siswa yang teridentifikasi memiliki IQ yang tinggi. Fenomena lainnya yaitu terdapat siswa berbakat yang memiliki prestasi yang baik, motivasi tinggi, IQ tinggi akan tetapi kesulitan menghadapi kekalahan ketika harus berkompetisi. 
Fenomena tersebut menjadi alasan peneliti untuk menemukan sejauhmana tingkat stres yang terjadi pada siswa berbakat dan kecenderungan pemilihan strategi yang tepat yang kemudian dibuatlah program yang tepat untuk mengelola stres siswa berbakat sebagai bahan untuk memfasilitasi pelayanan pendidikan.

\section{METODE}

Metode yang digunakan dalam penelitian ini menggunakan metode destkriptif dengan pengambilan sampel menggunakan nonprobability sampling secara khusus purposive sampling. Teknik ini menggunakan penentuan sampel dengan pertimbangan tertentu. Penentuan sampel didasarkan pada teori dari Renzulli yaitu, hasil skor IQ, tingkat komitmen terhadap tugas, dan tingkat kreativitas yang berada di atas rata-rata. Pengambilan sampel dari total populasi siswa di kelas $X$ sebanyak 389 orang, didapatkan sampel sebanyak 39 orang yang sesuai dengan kebutuhan.

Instrumen penelitian yang digunakan untuk mengukur gejala stres akademik siswa berbakat adalah angket. Instrumen penelitian ini disusun dan dikembangkan oleh penelit mengacu pada teori dari Lazarus dan Folkman. Selain mengungkap gejala stres akademik, dalam penelitian ini menggambarkan kecenderungan siswa berbakat dalam memilih strategi koping yang dilakukan. Untuk mengungkap kecenderungan tersebut peneliti mengembangkan instrument mengacu pada teori dari Lazarus dan Folkman serta instrument dari Carver yang dikembangkan dari teori Lazarus \& Folkman. Skala yang digunakan adalah skala likert yang bertujuan untuk mengukur sikap, pendapat atau persepsi. Alternatif jawaban pada angket gejala stres akademik menggunakan pilihan Selalu (SS), Sering (S), Kadang-kadang (KK), Jarang (J), Tidak Pernah (TP). Sedangkan skala yang digunakan pada sering dipergunakan (SP), Dipergunakan (P), Kadang Dipergunakan (KP), Jarang Dipergunakan (JP), dan Tidak dipergunakan sama sekali (TP). Skala ini mengacu pada kuesioner yang dikembangkan oleh Lazarus dan Folkman (1988) yaitu Ways of Coping Questionnaire.

Angket yang dibuat pada angket stres akademik sebanyak 69 pertanyaan. Setelah diuji validitas terdapat pernyataan yang tidak memadai sebanyak dua pernyataan yaitu pada angket dengan nomor 21 dan 30. Untuk angket strategi coping dibuat sebanyak 34 pernyataan. Setelah diuji validitas terdapat pernyataan yang tidak memadai sebanyak lima pernyataan yaitu pada angket dengan nomor 6,7,12,15, 22, 23, 28 dan 30. Kedua angket pernyataan yang tidak cukup memadai, tidak dipergunakan dalam penelitian. Dengan demikian jumlah pernyataan untuk angket stres akademik sebanyak 67 pernyataan 
dengan skala likert 1-5. Sedangkan untuk angket strategi coping sebanyak 26 pernyataan dengan skala likert 1-5.

\section{HASIL DAN PEMBAHASAN}

Hasil penelitian menunjukkan bahwa setiap aspek stres akademik siswa berbakat dari aspek fisik berada pada kategori sedang dengan persentase $46.63 \%$, pada aspek perilaku berada pada kategori sedang dengan persentase $30.94 \%$, pada aspek proses berpikir berada pada kategori sedang dengan persentase $44.24 \%$ dan aspek emosi berada pada kategori sedang dengan persentase $48.60 \%$. Dari keempat aspek tersebut, aspek emosi berada pada gambaran tertinggi dan yang terendah pada aspek perilaku. Selengkapnya seperti ditunjukkan pada Tabel 1.

Tabel 1. Gambaran Umum Setiap Indikator Gejala Stres Akademik Siswa Berbakat Kelas X SMAN 4 Bandung Tahun Ajaran 2015/2016

\begin{tabular}{|c|c|c|}
\hline Aspek & Indikator & Persentase \\
\hline \multirow[t]{5}{*}{ Reaksi Fisik } & 1. Sakit kepala & $55.84 \%$ \\
\hline & 2. Tubuh tidak mampu istirahat maksimal & $51.28 \%$ \\
\hline & 3. Kelelahan fisik & $41.31 \%$ \\
\hline & 4. Telapak tangan berkeringat & $47.44 \%$ \\
\hline & 5. Denyut jantung berdebar & $48.50 \%$ \\
\hline \multirow[t]{8}{*}{ Reaksi Perilaku } & 1. Berbohong & $42.95 \%$ \\
\hline & 2. Membolos atau mabal & $39.64 \%$ \\
\hline & 3. Menggerutu & $41.60 \%$ \\
\hline & 4. Menyalahkan orang lain & $46.84 \%$ \\
\hline & 5. Berkelahi & $47.09 \%$ \\
\hline & 6. Mencari perhatian orang lain & $47.69 \%$ \\
\hline & 7. Gugup & $54.31 \%$ \\
\hline & 8. Suka menyendiri & $47.99 \%$ \\
\hline \multirow{7}{*}{$\begin{array}{l}\text { Reaksi proses } \\
\text { berpikir }\end{array}$} & 1. Sulit konsentrasi & $45.01 \%$ \\
\hline & 2. Prestasi menurun & $50.95 \%$ \\
\hline & 3. Perfeksionis & $56.84 \%$ \\
\hline & 4. Kehilangan harapan & $30.34 \%$ \\
\hline & 5. Tidak memiliki prioritas hidup & $40.33 \%$ \\
\hline & 6. Berpikir negatif & $27.35 \%$ \\
\hline & 7. Jenuh & $54.50 \%$ \\
\hline \multirow[t]{4}{*}{ Reaksi emosi } & 1. Cemas & $46.85 \%$ \\
\hline & 2. Mudah tersinggung & $48.32 \%$ \\
\hline & 3. Tidak merasakan kepuasan & $51.92 \%$ \\
\hline & 4. Merasa diabaikan & $46.47 \%$ \\
\hline
\end{tabular}

Dapat disimpulkan bahwa gambaran umum setiap aspek stres akademik siswa berbakat berada pada tingkat sedang. Sedangkan gambaran persentase tertinggi berada pada aspek emosi dengan persentase $48.60 \%$. Pada kategori 
tersebut, siswa memerlukan perhatian khusus untuk mengelola stres akademik pada beberapa aspek dengan adanya program bimbingan dan konseling yang dengan kebutuhan yang telah diuraikan.

Gambaran umum tersebut sejalan dengan penelitian yang dilakukan oleh Meigawati (2014) menunjukkan bahwa tingkat stres akademik siswa kelas X di SMAN 19 Bandung ditinjau dari keyakinan diri termasuk pada tingkat sedang. Namun, berbeda dengan penelitian yang dilakukan oleh Wahyuningsih (2011) terhadap siswa SMP di kelas akselerasi dan non akselerasi. Hasilnya menunjukkan bahwa siswa di kelas akselerasi memiliki kecenderungan stres akademik yang cukup tinggi dengan persentase $45,54 \%$ dibandingkan dengan kelas non akselerasi dengan $8.11 \%$. Sejalan dengan penelitian Wahyuningsih, penelitian yang dilakukan oleh Rahayu (2014) di SMAN 2 Tangerang Selatan terhadap siswa akselerasi. Hasilnya menunjukkan bahwa siswa kelas akselerasi memiliki kecenderungan stres akademik tinggi dengan persentase sebesar $51.4 \%$.

Berdasarkan hasil dua penelitian di tingkat yang berbeda dengan latar belakang yang sama memiliki hasil yang penelitian serupa yaitu kecenderungan stres akademik di sekolah akselerasi berada pada tingkat tinggi. Berbeda dengan penelitian yang dilakukan oleh Meigawati di tingkat sekolah reguler dengan hasil penelitian kecenderungan stres siswa berada pada tingkat sedang. Hal tersebut dapat disebabkan karena latar belakang pendidikan dan konsep sekolah dan tuntutan akademik yang berbeda.

Menurut Lazarus dan Folkman (1984), stres terjadi jika individu menganggap bahwa kemampuan yang dimiliki tidak dapat memenuhi tuntutan lingkungan sehingga timbul tekanan dalam diri individu. Selye (1999) memaparkan bahwa stres merupakan reaksi spefisik antara individu dengan lingkungan yang dinilai sebagai suatu hal yang mengancam bagi individu. Hal yang mengancam tersebut adalah tuntutan yang dirasakan tidak sesuai dengan kemampuan yang dimiliki sehingga untuk memenuhi tuntutan individu diperlukan kemampuan menghadapi hambatan tersebut. Sejalan dengan pernyataan yang dikemukakan oleh Santrock (2003: 557) bahwa stres merupakan respon individu terhadap suatu keadaan yang memicu stres sehingga individu memerlukan kemampuan untuk menanganinya. Seperti yang telah dikemukakan oleh beberapa ahli stres muncul akibat dari stressor. Apabila semakin banyak tuntutan dari lingkungan kemudian kemampuan diri tidak dapat teroptimalkan dengan baik maka akan menimbulkan stres. Adapun hasil penelitian yang telah dilakukan menggambarkan siswa berbakat berada di tingkat sedang disebabkan sebagian siswa berbakat menganggap tidak semua 
tuntutan yang ditujukan mengancam pada siswa sehingga apa yang diharapkan sesuai dengan keinginannya.

Silverman (Harjaningrum et al, 2007: 123) memaparkan banyak ahli psikologi pendidikan dan anak-anak berbakat yang mengatakan bahwa, semakin tinggi perkembangan intelegensi anak tersebut, maka anak akan mengalami efek dari ekstremitasnya, yaitu mempunyai berbagai gangguan baik fisik, motorik, sosial, emosional dan perilaku. Sejalan dengan pendapat yang dikemukakan oleh Silverman, hasil penelitian gambaran setiap aspek stres akademik tertinggi berada pada aspek emosi. Strung (Tirtonegoro, 2001) berpendapat bahwa sensitivity ekstreme perlu bagi para anak berbakat untuk menciptkaan sesuatu yang sangat tinggi nilainya. Hal ini yang menjadi sebab siswa berbakat ekstrensik dan sangat mudah terpengaruh oleh gangguan emosional.

Tidak sedikit dari siswa yang mengalami disinkronitas perkembangan baik secara fisik maupun psikisnya. Hal tersebut diakibatkan karena karakterisik siswa berbakat yang memiliki kecenderungan untuk berpikir jauh dari seusianya sehingga faalangst atau rasa takut. Rasa takut tersebut disebabkan karena faktor kuat siswa berbakat yang memiliki kecenderungan memiliki dorongan motivasi internal kuat sehingga jika tidak mendapatkan apa yang diingingkan akan berusaha untuk mencapainya (Mooij, 1991b, dalam Harjaningrum et al, 2007).

Salah satu karakteristik yang khusus pada siswa berbakat lainnya yaitu rasa tidak puas yang berasalasan, bagi siswa lain mungkin ketika mendapatkan prestasi yang bagus akan cukup puas namun, berbeda dengan siswa berbakat, kemampuan siswa berbakat untuk mencapai hasil diinginkan menjadi faktor kuat (Flieger, dalam Harjaningrum et al, 2007). Hal tersebut akan berdampak negatif sehingga menimbukan masalah disinkronitas antara harapan dan keinginan yang memungkinkan terjadinya stres jika hal tersebut tidak diarahkan dengan tepat. Hal tersebut sejalan dengan hasil penelitian pada setiap indikator pada aspek emosi yaitu tidak merasakan kepuasan dengan persentase sebesar $51,92 \%$. Stres yang yang tidak ditangani secara tepat cenderung berimplikasi pada depresi (Hidayat \& Sahrudin, 2016: 174).

Harjaningrum (2007) memaparkan dalam memberikan arahan agar siswa berbakat dapat memutuskan permasalahan dengan cara yang tepat. Bila siswa berbakat melakukan trial and error tanpa bimbingan, dengan karakteristik yang dimilikinya siswa berbakat akan menemukan cara-cara yang dirasanya cocok, maka cara tersebut akan sulit diperbaiki karena peserta berbakat memiliki karakteristik perfeksionis yang dapat memungkinkan ketidakflesibelan terhadap perubahan. Sikap ini akan jadi positif jika menanggapi dengan baik. Sebaliknya akan berdampak negatif jika memaksakan kehendaknya, terlebih 
ketika hal tersebut bersinggungan dengan aktivitas sosial lainnya. Pernyataan ini sejalan dengan hasil penelitian yang dilakukan oleh peneliti terkait indikator tertinggi pada aspek perilaku yaitu sikap perfeksionis dengan persentase sebesar $56.84 \%$

Jika perkembangan baik dari segi fisik, psikis, motorik, sosial, emosional dan perilaku ini tidak diarahkan dengan tepat karena adanya faktor kuat yaitu adanya standar tinggi antara harapan yang telah siswa berbakat tentukan sebelumnya dan tidak sesuai dengan kehendaknya dampak ekstrem yang terjadi adalah mengalami depresi (Meckstroch \& Tolan, 200, dalam Harjaningrum et al, 2007). Pada hakikatnya siswa berbakat mempunyai kemungkinan besar untuk mencapai hasil yang baik, namun pada suatu waktu tertentu dapat pula mengalami kegagalan yang disebabkan berkembangnya rasa tidak percaya diri seperti ketika suatu harapan tidak sesuai dengan keinginan dan adanya faktor lingkungan yang memiliki tuntutan berlebih. Ketidakseimbangan antara perkembangan, karakteristik dan kenyataan secara ekstrem dapat menimbulkan perilaku menyimpang sehingga perlu adanya arahan atau pemberian bantuan yang tepat yaitu dengan adanya pelayanan pendidikan yang tepat untuk mengelola stres yang dialami oleh siswa baik secara preventif maupun responsif.

Pada kecenderungan pemilihan strategi koping siswa berbakat, hasil penelitian menunjukkan bahwa siswa berbakat lebih banyak menggunakan strategi coping pada Emotion Focused Coping Problem dengan persentase sebesar 53.84\%. Emotion Focused Coping merupakan usaha individu menyelesaikan masalah dengan mengatur respon emosional dalam rangka menyesuaikan diri (Lazarus dan Folkman, 1984). Respon emosinal yang dimaksudkan dalam bentuk menjauhkan diri atau berusaha tidak melibatkan diri sehingga cenderung menyendiri. Selain itu berusaha menghindari masalah tersebut bukan terfokus pada penyelesaian masalah tapi bagaimana masalah tersebut dihindari. Hal tersebut sejalan dengan sikap negatif siswa berbakat yang diungkapkan oleh Tirtonegoro (2001) bahwa siswa berbakat memiliki ciri senang menyendiri, menyelesaikan segala sesuatu sehingga mereka lupa terhadap tugas, atau permasalahan yang mereka hadapi sehingga mereka terisolasi.

Sesuai dengan karakteristik dari siswa berbakat yaitu perfeksionis, ketika siswa berbakat memaknai permasalahan dengan cara demikian maka akan menimbulkan faalangst. Faalangst ini merupakan kelemahan siswa berbakat yang disebabkan oleh karakteristik perfeksionisme yang dimiliki. Jika siswa lebih banyak menggunakan Emotional Focused Coping akan memunculkan 
rasa percaya diri yang rendah dan konsep diri negatif (Harjaningrum, et al, 2007).

Sejalan dengan penelitian yang dilakukan oleh Pratiwi (2015) terhadap siswa SMP sebelum melakukan treatment cenderung memilih strategi koping emotional focused coping, kemudian setelah diberikan perlakuan dengan menggunakan strategi problem focused coping mengalami penurunan pada empat aspek yaitu fisik, perilaku, emosi dan proses berpikir. Berbeda dengan hasil penelitian yang dilakukan oleh Rahayu (2014) terhadap siswa di SMA Negeri 2 Tangerang Kelas Akselerasi menyatakan siswa lebih banyak mengatasi permasalahan yang dihadapi pada coping adaptif dengan persentase sebesar 51.4\%. Penelitian yang serupa dilakukan oleh Rosita (2016) kepada mahasiswa Psikologi angkatan 2013, 2014, dan 2015 di Universitas Padjajaran mengenai gambaran bentuk strategi coping pada tingkat mahasiswa hasil menunjukkan mayoritas partisipan lebih banyak menggunakan problem focused coping sebesar $48.3 \%$.

Pada hakikatnya siswa berbakat memiliki kepercayaan diri yang tinggi sehingga meraka melihat suatu masalah sebagai sebuah tantangan yang bisa diselesaikan dengan cara mereka sendiri sehingga sebenarnya siswa berbakat dapat melakukan coping yang positif sebagai cara untuk memecahkan permasalahan. Maka dari itu perlu adanya bantuan yang tepat berupa layanan yang sesuai kepada siswa berbakat.

\section{SIMPULAN}

Stres akademik siswa berbakat kelas $X$ di SMAN 4 Bandung Tahun Ajaran 2015/2016 berada pada kategori sedang. Artinya, sebagian besar siswa cukup mampu mengelola stres akademik. Siswa berbakat kelas $X$ di SMAN 4 Bandung Tahun Ajaran 2015/2016 lebih banyak menggunakan strategi coping pada aspek Emotional Focused Coping. Artinya bahwa siswa berbakat cenderung mengatasi permasalahan dengan menggunakan strategi coping berfokus terhadap emosi.

Stres akademik siswa berbakat yang rata-rata di tingkat sedang menunjukkan bahwa sebagian indikator stres dialaminya, dengan demikian siswa berbakat masih memerlukan perhatian khusus untuk mengelola dan mengelola stres akademik, oleh karena itu, diperlukan bantuan dari pihak lain. Upaya yang dapat dilakukan guru Bimbingan dan konseling adalah melaksanakan program yang telah direncakan untuk mengelola stres akademik siswa berbakat dengan mempertimbangkan deskripsi kebutuhan dan kondisi sasaran. Selain itu, guru 
Bimbingan dan Konseling memfasilitasi kebutuhan siswa agar dapat mengoptimalkan potensinya.

Guru mata pelajaran dan wali kelas diharapkan dapat berkolaborasi dengan guru bimbingan dan konseling untuk memantau perkembangan siswa berbakat. Guru mata pelajaran dan wali kelas dapat memfasilitasi pembelajaran di kelas dengan menciptakan lingkungan belajar yang efektif dan sesuai kebutuhan. Hal tersebut guna memberikan pengaruh yang baik terhadap siswa berbakat.

Hasil penelitian mengenai stres akademik siswa berbakat kelas X SMAN 4 Bandung Tahun Ajaran 2015/2016 diharapkan dapat menjadi bahan kajian dan pengetahun. Pada penelitian ini peneliti menggambarkan stres akademik dan kecenderungan pemilihan strategi koping, maka diharapkan pada penelitian selanjutnya dapat dilakukan penelitian terkait hubungan stressor dengan reaksi stress dan penggunaan strategi koping dan pengaruhnya dalam kehidupan sehari-hari.

\section{REFERENSI}

Aldwin, C. M. (2007). Stress, coping, and development: An integrated perspective (2nd ed.). New York: Guilford.

Aldwin, M. C., \& Yancura, A. L. (2004). Coping and health: A comparasion of the stres and trauma literatures. Washington, DC: American Psychological Association.

Beck, R., \& Judith, S. (1998). Cognitive Behavioral Therapy in the Treatment. New York: Longman Publishing.

Harjaningrum, A. T., Inayati, D. A., Wicaksono, H. A., \& Derni, M. (2007). Peranan orang tua dan praktisi dalam membantu tumbuh kembang anak berbakat melalui pemahaman teori dan tren pendidikan. Jakarta: Prenada.

Hidayat, A., \& Sahrudin, A. (2016). Locus of Control in Late Adolescence: Characteristics and Ability of New Students to Overcome Depression. GUIDENA: Jurnal IImu Pendidikan, Psikologi, Bimbingan dan Konseling, 6(2), 172-179.

Kitano, M. K., \& Kirby, D. F. (1986). Gifted Education: comprehensive vies. Boston: Little, Brown and Company.

Lazarus, R. S., \& Folkman, S. (1984). Stress, appraisal and coping. New York: Springer. 
Meigawati, D. (2014). Profil stress akademik ditinjau dari keyakinan diri akademik siswa kelas X SMAN 19 Bandung tahun ajaran 2013/2014. (Skripsi, Universitas Pendidikan Indonesia, Bandung).

Misra, R., \& McKean, M. (2000). College students' academic stress and its relation to their anxiety, time management, and leisure satisfaction. American Journal of Health Studies, 16(1), 41-51.

Munandar, U. (2002). Pengembangan kreativitas anak berbakat. Jakarta: Rineka Cipta.

Munandar, U. (2014). Kreativitas dan keberkabatan strategi mewujudkan potensi kreatif dan bakat. Jakarta; Gramedia Pustaka Utama.

Rahayu, F. (2014). Hubungan Tingkat Stres dengan strategi coping siswa-siswi akselerasi SMA Negeri 2 Kota Tangerang. (Skripsi, Universitas Islam Negeri Syarif Hidayatullah, Jakarta).

Rosita, S. (2016). Gambaran bentuk coping stress mahasiswa fakultas psikologi universitas padjajaran yang mengalami stres akademik. (Skripsi, Universitas Padjajaran, Bandung).

Santrock, J. W. (2002). Life-span development. Jakarta; Erlangga.

Tirtonegoro, S. (2001). Anak supernormal dan program pendidikannya. Yogyakarta: Bumi Aksara. 